\title{
Monitoring of Solid Particulate Airborne Samples from Mountain Snow in Some Sites of the Alps, Italy
}

\author{
C. Telloli ${ }^{{ }^{*}}$, M. Fazzini ${ }^{2}$, R. Tassinari ${ }^{2}$, E. Marrocchino ${ }^{2}$, C. Vaccaro $^{2}$ \\ ${ }^{1}$ Italian National Agency for New Technologies, Energy and Sustainable Economic Development (ENEA), \\ Technical Unit for Environmental Assessment Models, Methods and Technologies (UTVALAMB), \\ Air Quality Laboratory (AIR), Bologna, Italy \\ ${ }^{2}$ Department of Earth Science, Ferrara University, Ferrara, Italy \\ Email: *chiara.telloli@enea.it
}

Received April 2, 2013; revised May 5, 2013; accepted June 4, 2013

Copyright (C) 2013 C. Telloli et al. This is an open access article distributed under the Creative Commons Attribution License, which permits unrestricted use, distribution, and reproduction in any medium, provided the original work is properly cited.

\begin{abstract}
In the last decades, few days a week, several city centres in Italy are closed at vehicular traffic in order to limit the presence of particulate matter, often exceeding the limits set by law [1,2]. The particulate matter have an impact on human health $[3,4]$, in the cultural heritage and natural environment deterioration [5,6]. Many studies have been the carried out in air monitoring in urban areas while the targeted surveys to assess the impact on air quality of snow dispersion for ski activities are rare. Thanks to the Autonomous Province of Trento it has been possible to sample the snowpack in some ski areas in Italy and thanks to stratigraphic profiles it has been possible to observe variations of the chemical composition over time. Natural contribution is strictly related to winds and currents movement, for this reason a deep knowledge of these factors can help in the determination of the prevalent trajectories during the year [7,8]. During a penetrometeric and stratigraphic profile on Presena glacier, the main nivo-meteorological features, air temperature and temperature inside the different layers of the snowpack have been measured. Some snow samples has been collected and analyzed by SEM-EDS, ICP-MS and IC. These qualitative and quantitative analyses allow to obtain chemical and mineralogical composition to define the emitting source.
\end{abstract}

Keywords: Air Quality; Dolomites; $\mathrm{PM}_{10}$; $\mathrm{PM}_{2,5}$; SEM-EDS; IC; ICP-MS

\section{Introduction}

The study of particulate matter in the snow is not common and few studies are related to the campaigns carried out in Antarctica. Most of the scientific works in Europe verifies the impact of large communication structures on the quality of the snow. This analysis assesses the contributions of local impact on air quality but also verifying the contributions of transboundary aerosol and defines the levels of background, to estimate the impact. It is assumed that the snow sampling particulate matter in the atmosphere during the fall, providing information on the chemical characteristics of the air column crossed. Quantify the changes in the chemistry of snow can be useful to complete the balance of the contributions of particulate matter to the soil and their effects on the ecosystem, knowing that they have potential negative environmental [9-11]. In addition, the trace elements may allow to recognize traces of various sources of aerosols both natural

\footnotetext{
Corresponding author.
}

and anthropogenic [12].

Precipitation, liquid and solid, are important mechanisms of atmospheric deposition, especially in remote areas. Several studies, from the last 20 - 30 years [13], have shown that collect samples of precipitation often is efficient in trace the sources and reconstruct the transport routes. In fact, some studies have emphasized the importance of know the falling snow to recognize both the aerosol particles and the phases of volatile organic compounds from the atmosphere [14,15]. These empirical and theoretical studies suggest that the snow has a great efficiency in both maintain the particles that the gaseous phases of organic compounds with respect to the rains, for this reason the snow plays an important role in contamination of the environment [16].

The monitoring stations of particulate are difficult to be managed in mountainous areas, which are characterized by long periods with thermal states below zero. Nevertheless, these areas are particularly interesting for the analysis of transboundary aerosol, both for the low 
human impact that for their localization at high altitudes. Therefore, the present study evaluated the potential of chemical and morphological characteristics of the particles, to determine local and transboundary contributions through samples of stratigraphic sections of snow that have taken place during the entire winter 2010. Some researchers have shown that it is not negligible the impact that the contaminants accumulated during the winter season can have on natural resources during and after the melting of snow in spring $[17,18]$. In areas of permanent snow and glaciers, contaminants may be subject to deep burial resulting in inclusion in the layers of ice $[19,20]$. Hence the possibility of having information on the evolution over time of the particulates, through the study of carrots performed in glaciers [19,21,22].

The estimation of the particulate in the snow also has repercussions on the evaluations of the overall energy balance, since the impurities and the sizes of the particles control the absorption of solar radiation, while the temperature controls the emission of radiation at low wavelengths [23]. At visible light $(0.4$ to $0.7 \mu \mathrm{m})$, the ice is weakly absorbing and particles in the snow will trigger the light. Consequently, the pure snow has an albedo very large $(>0.9)$ (radius of the radiative flux reflected on the incident radiative flux). The albedo of snow visible is very sensitive to impurities, such as soot, dust and fragments of vegetation.

Some models have shown that the high absorption of small particles in concentrations of about $1 \mathrm{ppm}$ may decrease the albedo of the visible snow, mainly due to the reduction of the coefficient of scattering. In some studies it has been shown that the albedo decreases exponentially from $20 \%$ to $60 \%$ in perennial snow with a particulate concentration from $10^{2}$ to $10^{3}-10^{4} \mu \mathrm{g} / \mathrm{m}^{3}[24,25]$.

In literature, studies carried out on the snow and ice of Greenland and Antarctica have shown the presence of toxic trace elements (lead and cadmium). On the basis of stratigraphic position and historical assessments based on light isotopes, it was possible to interpret the causes of these enrichments, attributing the anomalies in atmospheric emissions from anthropogenic sources in the period of the Greek-Roman two millennia before the Industrial Revolution, probably due to ancient mining and smelting activities $[26,27]$. These anomalies are characterized by relations between elements for emission sources of the industrial revolution. Air pollution from 1700 to the present has been documented for several heavy metals, including $\mathrm{Pb}, \mathrm{Cd}, \mathrm{Cu}$ and $\mathrm{Zn}$ [28-30], $\mathrm{Hg}$ [31], Pt, $\mathrm{Pb}$ e $\mathrm{Rh}$ [32]. Studies on the snows and glaciers of Antarctica have made it clear that the natural cycles of trace elements such as $\mathrm{Cr}, \mathrm{Cu}, \mathrm{Zn}, \mathrm{Ag}, \mathrm{Pb}, \mathrm{Bi}$ and $\mathrm{U}$, were widely disrupted in the oldest Antarctic atmosphere, especially in recent years, and these disturbances reflect the stage of advancement of technology and metallurgical processes.
This is mainly due to long-range transport of pollutants from artificial sources of the surrounding areas, such as South America, South Africa and Australia [33-38]. Geochemical data obtained from the study of snow and glaciers in Greenland [39] and in the remote regions of Antarctica [40] and in the Arctic [41], have shown that the development of pollution with trace elements has become of global importance, and reflects the extent of human impact on natural geochemical cycle of these same elements. Recently, several studies have demonstrated the different relationship between trace elements and human activities in the snows and glaciers of the Alps and in the high altitudes of the glaciers Bolivia [32,42-49]. In recent studies, the concentrations of trace elements were measured in the snow at high altitudes in eastern Tien Shan [50], eastern Pamirs Mountains Muztagh Ata in northern China [51,52], on Mount Everest in the Himalayas [5355], in the Scottish mountains [56], in America [23] and in the Italian Alps [16,57]. From all these studies it is understandable that the concentrations of some trace elements vary from area to area.

The interest on the study of trace elements present in the snows and glaciers at mid-latitudes is of great interest, because of rapid economic growth and industrialization developed in recent decades, resulting in high levels of anthropogenic pollution in the atmosphere $[58,59]$. These studies have been done both in relatively remote areas, such as the Andes Mountains [60] and in populated areas as the European Alps $[43,48]$. The deposits of snow in the Alps testify the effects of anthropogenic emissions in Europe [61]. Recent samplings on Alpine glaciers have allowed to reconstruct the history of pollution of trace elements in the last century $[48,62]$. Nevertheless, detailed studies on the sources of the trace elements present in the Alpine snows are quite rare [63,64]. The importance of these studies is to find markers of anthropogenic emission potentially toxic in the snow and to implement defense mechanisms to protect the terrestrial and marine environment and to protect human health.

In this study we analyzed samples of snow, to distinguish the contributions of anthropogenic origin from those of natural origin, taking samples in the Dolomites in winter 2010. All samples were analyzed in ion chromatography and ICP-MS in order to know the chemical composition and in SEM-EDS for morphological characterization.

\section{Methods}

The samples were made in the central Dolomites and in the Adamello-Presanella Massif (Trentino Alto AdigeNorth of Italy), near Alpe Pampeago (Tesero-Val di Fiemme-Trento), in the snow fields of Monsorno (altitude $2010 \mathrm{~m}$ ), Tresca (altitude $2080 \mathrm{~m}$ ) and Presena Gla- 
cier (altitude $2730 \mathrm{~m}$ ). The Monsorno field presents an exposure S while the Tresca field with an exposure NNW, they are far from each other less than one kilometre (Figure 1). The Capanna Presena field present exposure $\mathrm{N}$ and is located at the base of the glacier. The sampling site is chosen mainly in remote areas to avoid contamination from nearby emissions from roads, villages, tourist stations, alpine huts and artificial snow cannons.

Val di Fiemme is one of the main valleys of the Dolomites and is located in eastern Trentino. Together with Val di Fassa and Val di Cembra, is the catchment area of Avisio, left tributary of the river Adige. This area is very large $\left(400 \mathrm{Km}^{2}\right)$ and it is approximately $180 \mathrm{Km}$ from Adriatic Sea. It is surrounded to the $\mathrm{N}$ with Dolomites of Gardena and Fassa (Bolzano), to E with Dolomites of Feltre and the Pale di San Martino (Community Primiero), to SE with Pre Alpes Bellunesi (Community Valsugana), to $\mathrm{S}$ with Pre Alpes Vicentine, to $\mathrm{W}$ with Dolomites of Brenta and Alps of Val di Non (Community Cembra Valley), to NW with Alps Sarentine. The Dolomites di Fiemme are called mountains and not Dolomiti for their composition non-dolomitic, they shall consist, in fact, by silicate (granites and metamorphic rocks as porphyry) with a minor presence of carbonate and dolomite, and are located entirely in Trentino Alto Adige. The highest peak is Cima d'Asta with its $2847 \mathrm{~m}$ above sea level. During the winter season, Dolomitic area is often affected by strong continental thermal anticyclones that determine a mostly stable and very cold weather and lead to a strong minimum rainfall between December and February. The snowy weather conditions derived from passages of warm fronts from the Atlantic or the cyclogenesis on the Genoa Gulf, that attract masses of very hot and humid air from the Mediterranean (mainly orographic snowfall).

During the different phases of sampling, the main meteorological characteristics were collected at an altitude from $1760 \mathrm{~m}$ to $2730 \mathrm{~m}$ : air temperature and temperature of the superficial layer of the snow. Through the penetrometric battage profile, it was possible analysed a layer of snow of $4 \mathrm{~m}$ depth (Ghiacciaio Presena-2730 m), identifying each individual substrate. Then, through a process of dec-climatological analysis it was possible to

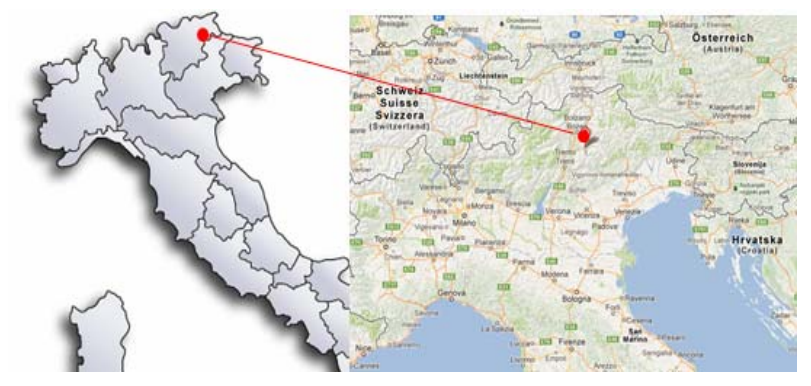

Figure 1. Map of the sampling site. know the sources that produce volcanic ash, or desert sands, or other contributions of transboundary aerosol. During the stratigraphic analysis, some samples were collected through coring and they were subsequently analyzed by SEM, ICP-MS and ion chromatography in the Department of the University of Ferrara, allow to obtain qualitative and quantitative analysis of the snow, and defining the chemical composition to know the source of emission.

The sampling was done in Pampeago Alp and in Presena Glacier at different times of the year 2010, during monitoring season of avalanches. February 18, March 11, April 11, May 12, therefore different meteorological conditions cannot be avoid. The meteorological data (temperature, humidity, wind direction and wind velocity) were respectively provided by METEOTRENTINO weather station of Cavalese-Alpe Cermis and Capanna Presena $(2750 \mathrm{~m})$. The first weather station is situated at $2200 \mathrm{~m}$ and was the nearest station to Pampeago Alps. The distance from station to sampling sites ranged from 4 to $5 \mathrm{~km}$ from SSW. Near the snow field of Capanna Presena automatic weather station complete with snow gauge ultrasonic is placed.

The sampling during the first campaign (February 18, 2010) was carried out from 10 am to $13 \mathrm{pm}(\mathrm{UTC}+1)$. The synoptic situation is characterized by a depression centred on Ireland, with a secondary low pressure field located on the ground near the Corsica Island and at high altitude (500 $\mathrm{hPa}$ geopotential) on the south of Sardinia. This facilitated the arrival of humid and warm current from southern Mediterranean basin (Libeccio at middle altitude and Scirocco at ground) to the Dolomites, with moderate snowfall above $1200 \mathrm{~m}$. The average wind speed were $3 \mathrm{Km} / \mathrm{h}$ and direction to the south (the trajectories were created using the software online NOAA HYSPLIT MODEL-GDAS Meteorological Data-Figure 2(a)). High values of relative humidity (about 74\%), associated with mild climate even in the mountain $\left(0^{\circ} \mathrm{C}\right.$ level at $1600 \mathrm{~m}$ with temperatures between $-3^{\circ} \mathrm{C}$ and $-1^{\circ} \mathrm{C}$ at $2200 \mathrm{~m}$ ) and snowfall events, reduced the aerosol particles resuspension. Three samples were collected. These samples were all used for the SEM-EDS analysis. The sampling during the second campaign (March 11, 2010) was carried in Pampeago out from 10:30 am to 12:30 am (UTC + 1). During March, the depression migrated from NW to NE Italy. This created mild and very moist southern currents to the dolomitic area. The average wind speed were $7 \mathrm{Km} / \mathrm{h}$ and the direction were from south-east (Scirocco-Figures 2(b) and 3(b)). High values of relative humidity $(68 \%)$ and mild temperatures (at $2200 \mathrm{~m}$ temperatures between $-3^{\circ} \mathrm{C}$ and $+1{ }^{\circ} \mathrm{C}$ ) during the day, with a light snowfall caused the reduction of the aerosol resuspension. For this sampling, three samples were collected: $30 \mathrm{~cm}$ depth, $70 \mathrm{~cm}$ depth and $130 \mathrm{~cm}$ depth. 
NOAA HYSPLIT MODEL

Backward trajectories ending at 0000 UTC 18 Feb 10 GDAS Meteorological Data

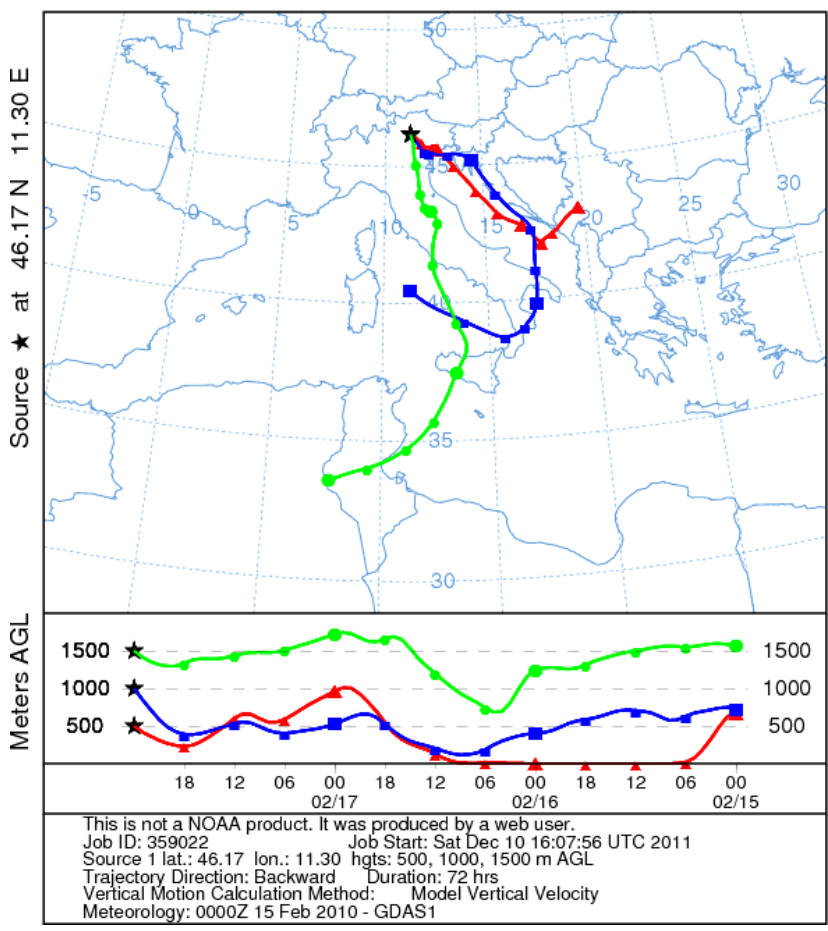

(a)

NOAA HYSPLIT MODEL

Backward trajectories ending at 0000 UTC 11 Apr 10 GDAS Meteorological Data

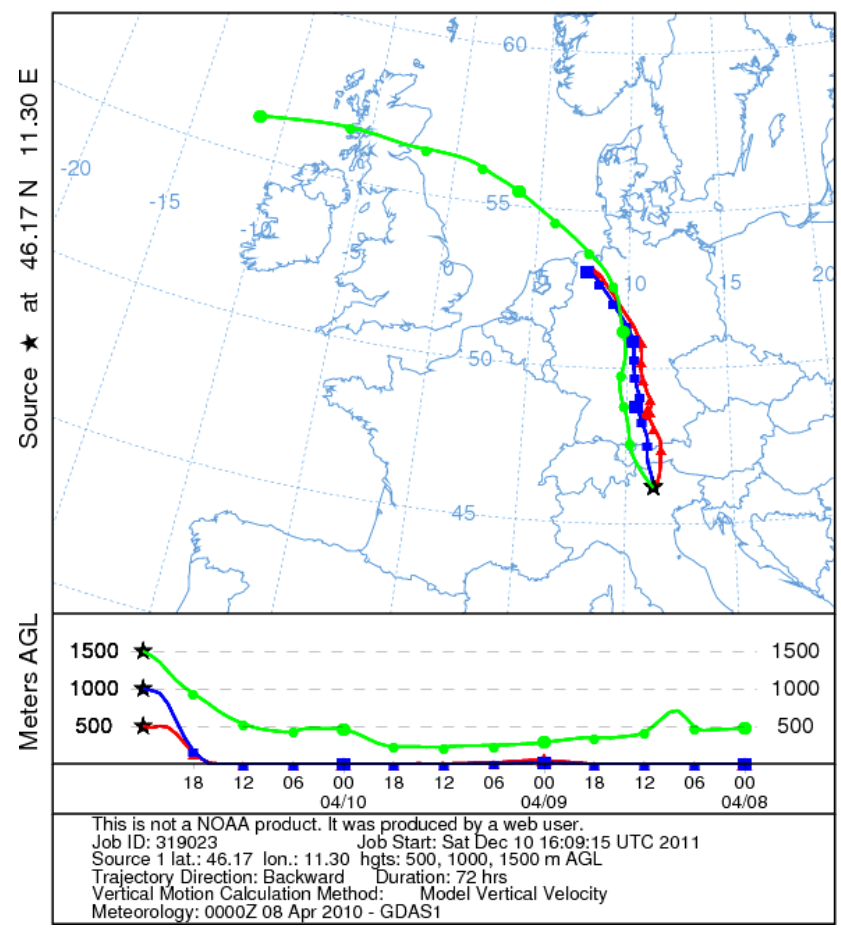

(c)
NOAA HYSPLIT MODEL

Backward trajectories ending at 0000 UTC 11 Mar 10 GDAS Meteorological Data

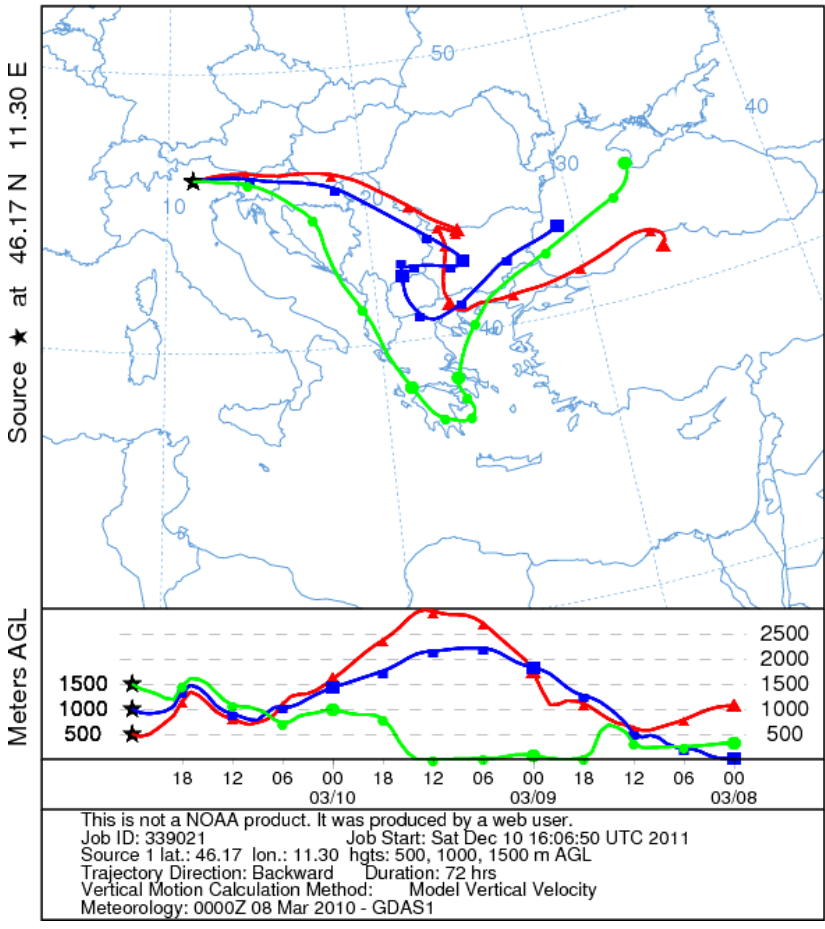

(b)

NOAA HYSPLIT MODEL

Backward trajectories ending at 0000 UTC 12 May 10 GDAS Meteorological Data

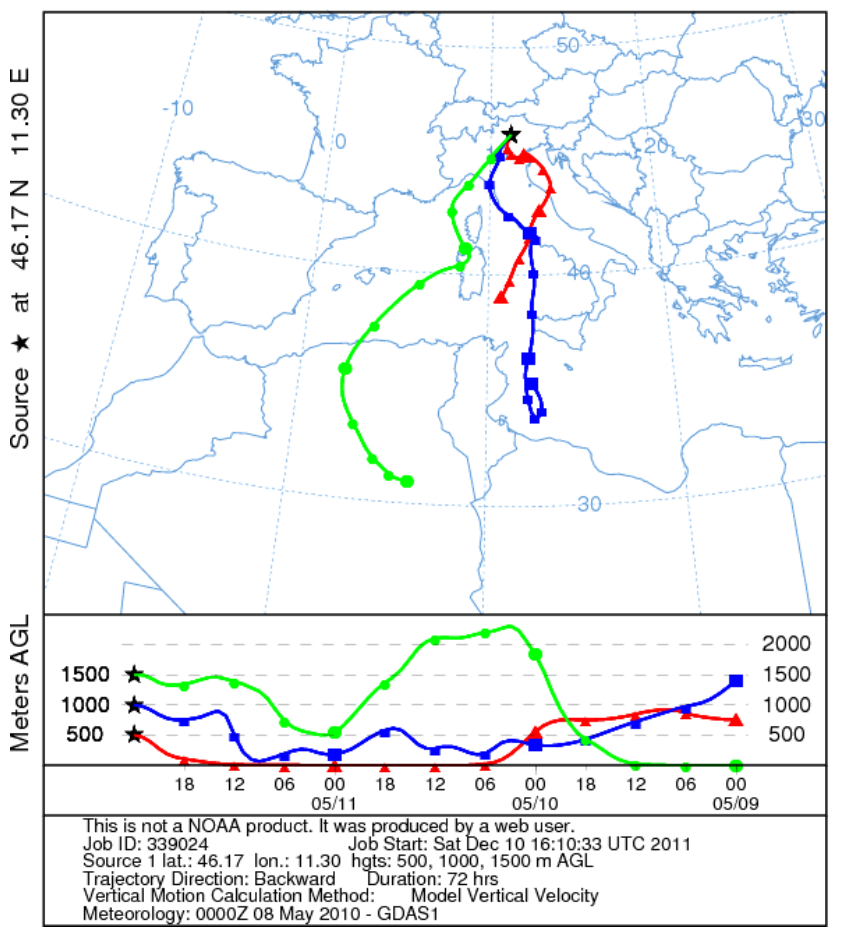

(d)

Figure 2. Back trajectories of the sampling days in the Dolomites (Software online NOAA HYSPLIT MODEL): (a) February, 18; (b) March, 11; (c) April, 11; (d) May, 12. 

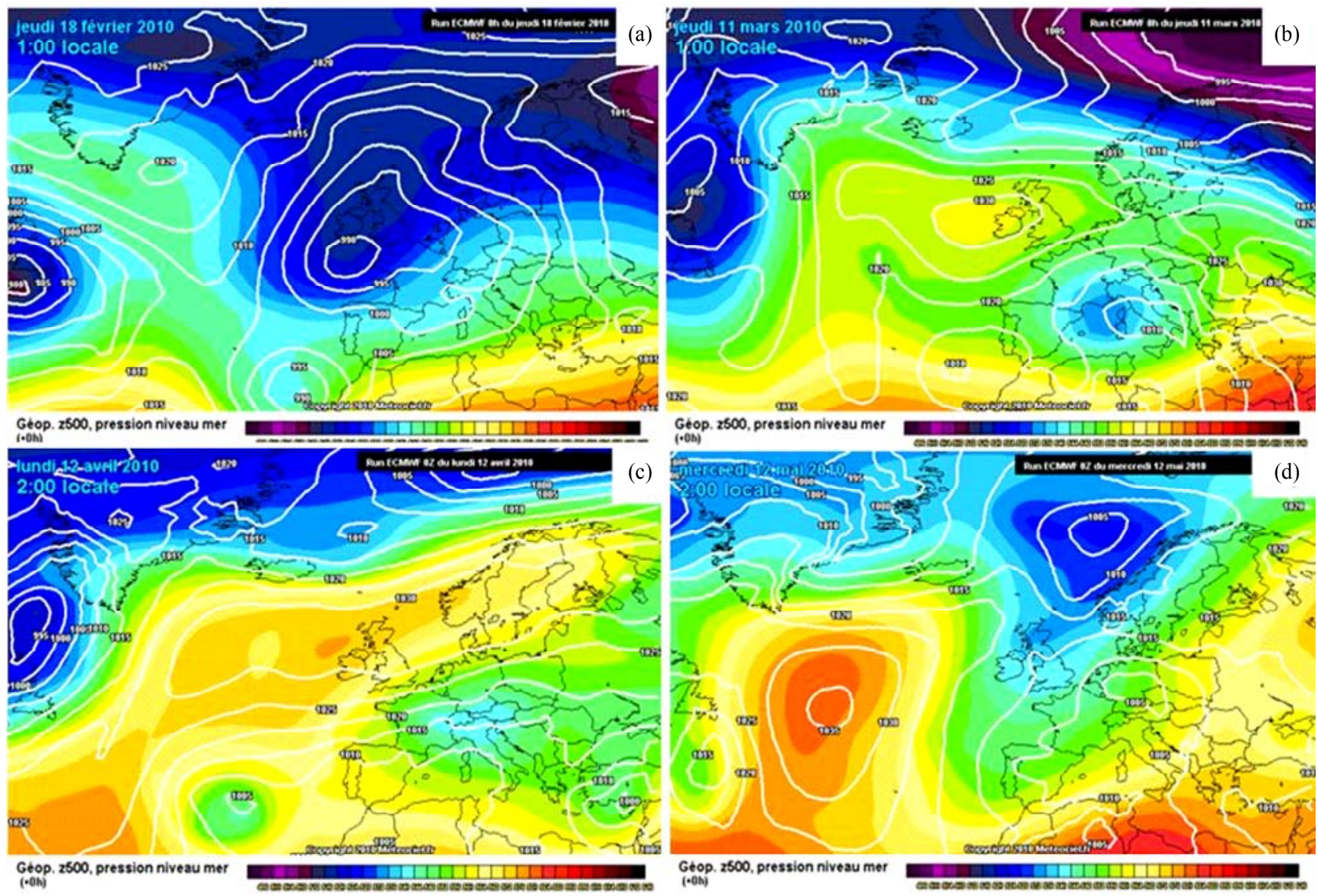

Figure 3. Atmospheric pressure on the ground and geopotential at 500 hPa to 00UTC: (a) February, 18; (b) March, 11; (c) April, 12; (d) May, 12.

The sampling during the third campaign (April 11, 2010) was carried out at the Presena Glacier $(2750 \mathrm{~m}$ from $12 \mathrm{am}$ to $2: 30 \mathrm{pm}(\mathrm{UTC}+1)$. The synoptic situation is characterized by inflow of cold air from the northeastern and arising from thermal contrast between the Russian anticyclone and a depression extending from eastern France and Styria. These currents cause a sudden drop in temperature, with variable weather and isolated snow showers over $1000 \mathrm{~m}$. At $2500 \mathrm{~m}$, the average wind speed and direction were $9 \mathrm{Km} / \mathrm{h}$ and from the north (Figures 2(c) and 3(c)). Low values of relative humidity (37\%) and temperature $\left(\mathrm{T}_{\min }-8^{\circ} \mathrm{C}\right.$ and $\mathrm{T}_{\max }-3^{\circ} \mathrm{C}$ at 2730 $\mathrm{m})$ maintained the environment stable and wet during the sampling. Also for this sampling, three samples were collected: $40 \mathrm{~cm}$ depth, $100 \mathrm{~cm}$ depth and $140 \mathrm{~cm}$ depth.

The sampling during the fourth campaign (May 12, 2010) was carried out from 11 am to 2:30 pm (UTC + 1) at Presena Glacier. The synoptic situation shows a range of pressures levelled to a low centre of south-western Europe with a strong anticyclone located on North Africa (Figure 3(d)). Therefore, on observe an active moderate humid south westerly flows. Sky mostly cloudy both without precipitation. The average wind speed and direc- tion were $5 \mathrm{Km} / \mathrm{h}$ and from the south (Figure 2(d)). At $2750 \mathrm{~m}$, values of relative humidity is around $84 \%$ while the temperatures are quite high and between $-2^{\circ} \mathrm{C}$ to $4^{\circ} \mathrm{C}$. For this last sampling, five samples were collected: on the ground level (surface layer), $170 \mathrm{~cm}$ depth, $250 \mathrm{~cm}$ depth, $300 \mathrm{~cm}$ depth and $310 \mathrm{~cm}$ depth.

\section{Analysis}

The instruments used for sampling were simple plastic tins, previously cleaned with MilliQ ${ }^{\circledR}$ water, with doublesealed cap. After collection, all samples were transported in a refrigerated cooler to UNIFE laboratory in Ferrara and stored under refrigeration until microscopy analysis was performed [65].

The samples were used for SEM-EDS analysis to characterize the shape and morphology and the elemental composition of aerosol particles collected. Morphological characteristics, size and elemental analysis of individual particles were performed with a Scanning Electron Microscopy (SEM) (Zeiss EVO 40) equipped with an Energy Dispersive X-ray Spectrometer (EDS) (INCA 300 OXFORD) for X-ray microanalysis. The particle size and the surface morphology of sampled aerosol par- 
ticles were investigated in high resolution mode (up to $20.000 \times$ ) with a working voltage of $20 \mathrm{kV}$ which correspond to the detection limit of $1 \mu \mathrm{m}$ particle size. The analyses were qualitative and were performed in the manually mode. SEM-EDS is often employed to identify airborne particulate deposits and biological materials [66]. In EDS, the X-ray detector measures the number of emitted X-rays as a function of their energy. Since elements have a characteristic energy, the EDS spectrum can be used to identify the quantity of elements present [67]. EDS technique is able to characterize the chemical composition of particles whose diameter is greater than 1 micron [68]. The Scanning Electron Microscopy is a technique employed in numerous atmospherically studies [65,68-73]. It is important to know that chemical and physical characterization of individual particles by SEMEDS instrument can reveal source information which cannot be determined through bulk chemical characterization. Each snow solution was placed in a specific centrifuge. There by the aerosol particles are attached to a film of titanium, which was subsequently analyzed by SEM. Other that, the filters, which were used for the preparations of the samples to analyzed in ICP-MS, were mounted on aluminum support SEM "stubs" with double-sided tape which had a conductive graphite-based. The samples were then coated with a thin layer of gold (coating) film by electric arc high vacuum method and then analyzed by SEM.

The multi-element analysis was carried out by Inductively Coupled Plasma Mass Spectrometry (ICP-MS, X Series spectrometer, collision/reaction cell $\mathrm{CCT}^{\mathrm{ED}}$, Thermo Electron Corporation), which has become an increasingly popular technique for characterization of atmospheric aerosols [74]. Multi-element characterization is done using a small sample volume, it has a large dynamic range (ppt or ppb) and a short analysis time [75-79]. For the ICP-MS the blank solution were prepared with $8 \mathrm{cc}$ $\mathrm{H}_{2} \mathrm{O}$ MilliQ ${ }^{\circledR}$, $1 \mathrm{cc}$ of standard Rh Re $(100 \mathrm{ppb})$ and $1 \mathrm{cc}$ of $\mathrm{HNO}_{3}$. The Limits of Detection (LOD) values were calculated as three times the standard deviation $(3 \mathrm{~s})$ of blanks. This analysis allows to recognize the geochemical fingerprint of the snow solution and to provide markers to identify anomalies related to the contributions of particles. Two different samples for each snow solution were prepared:

- $1 \mathrm{cc}$ of the snow solution was diluted with $8 \mathrm{cc} \mathrm{H}_{2} \mathrm{O}$ $\mathrm{MilliQ}^{\mathbb{R}}$ and $1 \mathrm{cc}$ of standard Rh Re (100 ppb);

- $50 \mathrm{cc}$ of the snow solution were filtered by syringe with a polypropylene VWR filter $0.45 \mu \mathrm{m}$. Then, $1 \mathrm{cc}$ of the snow filtered solution was diluted with $8 \mathrm{cc}$ $\mathrm{H}_{2} \mathrm{O}$ MilliQ ${ }^{\circledR}$ and $1 \mathrm{cc}$ of standard Rh Re (100 ppb).

For the IC analysis we used the ion chromatograph Dionex ICS2000, which uses of an eluent of carbonatebicarbonate. The anions are separated by an ion-exchange resin, low-capacity and highly basic and direct in a strong acid cation exchanger (suppressor), where they are converted into an acid form with high conductivity and the eluent is transformed into carbonic acid with weak conductivity. Therefore, the anions are measured for conductometry and compared with the standards on the basis of the retention times. The quantization is done by measuring the peak area or height. For IC analysis, $100 \mathrm{cc}$ of each snow solution samples were injected in the instrument and analyzed.

\section{Results and Discussions}

\subsection{Morphological Classification by SEM Analysis and Elemental Composition by SEM-EDS Microanalysis}

For each sample, SEM measurements were conducted on particles which were not in contact with any others. High-resolution images of particles were obtained by regulation of vacuum inside the instrument chamber. Several distinct particle shapes were observed, which were single particles rounded (Figure 4(a1)), angular (Figure 4(a2)) and amorphous (Figure 4(a3)); and agglomerate: rhomboedral/schalenoedral (Figure 4(b1)) and amorphous (Figure 4(b2)). The single particles were presents in a minor percentage $(38 \%)$ respect the agglomeration particles $(62 \%)$. The majority of single particles, randomly selected, were classified as amorphous particles (20\%), less rounded as particles (12\%) and a minority as angular particles $(6 \%)$. Instead of agglomerate particles were classified as amorphous particles (40\%) and a minority as rhomboedral/schalenoedral particles $(22 \%)$.

Aerosol composition of single particle was determined using EDS microanalysis which detected the presence of $\mathrm{C}, \mathrm{O}, \mathrm{Na}, \mathrm{Mg}, \mathrm{Al}, \mathrm{Si}, \mathrm{P}, \mathrm{S}, \mathrm{Cl}, \mathrm{K}, \mathrm{Ca}, \mathrm{Mn}$ and Fe. The chemical composition of the analyzed particles can be divided in five main categories: allumo silicate (Figure 4(a1)), silica (Figure 4(a2)), organic material (Figure 4(a3)), carbonate (Figures 4(b1) and (b2)) and sodium chloride (observed on the titanium film analyzed by SEM-EDS).

Figure 5 shows the chemical characterization of the particles analyzed by SEM-EDS. It can be noted that the majority of the particles were allumo silicate and sodium chloride and only a minority were silica and carbonate. This means that the particulate resuspended in the sampling zone in the Dolomites, is predominantly composed of resuspension of artificial snow and particles of anthropic local pollution.

\subsection{Chemical Composition by ICP-MS Technique}

The average concentrations in ppm and in percentage are reported in Figure 6, that shows variations in abundance 
between different elements as a function of the two solutions analyzed: "suspended" means the original snow solution and "filtered" means the solutions filtered by syringe with a polypropylene VWR filter $0.45 \mu \mathrm{m}$. The elements with negligible concentration are: $\mathrm{B}, \mathrm{Mn}, \mathrm{Cu}, \mathrm{Zn}$, $\mathrm{Sn}, \mathrm{Co}, \mathrm{Mo}, \mathrm{V}, \mathrm{Cr}, \mathrm{Ni}, \mathrm{Rb}, \mathrm{Sr}, \mathrm{Ba}, \mathrm{U}$. Toxic metals such as mercury, arsenic, vanadium nickel and cadmium were not found in any samples.

In general the concentrations are not representative, because so low, but it is important tom know the chemical composition of the snow, because the elements inside contributing to the water chemistry.

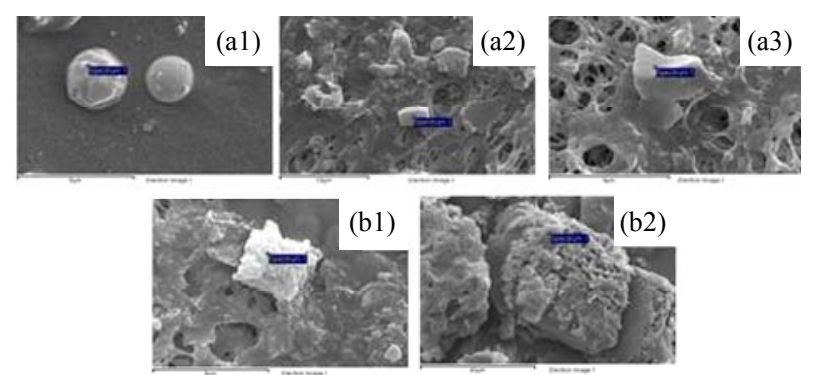

Figure 4. Images of representative particle shapes analyzed by SEM-EDS on the filters: single ((a1) round particle, (a2) angular particle, (a3) amorphous particle) and agglomerate ((b1) rhomboedral/schalenoedral particles, (b2) amorphous particles).

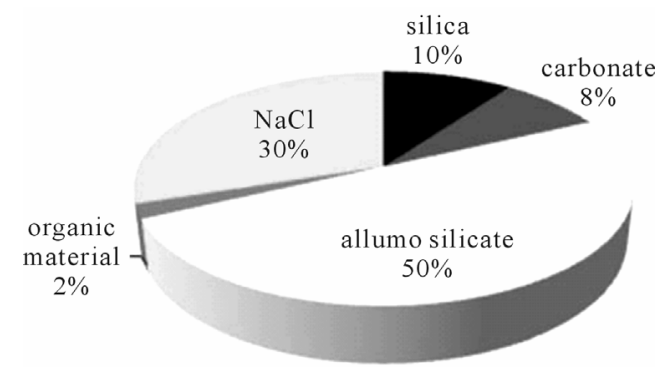

Figure 5. Characterizations of the particles in snow samples of each sampling (winter 2010) by SEM-EDS.
In all snow samples analyzed, it can observed high concentrations of calcium (\%) respect the other elements, that confirms the high presence of carbonates in the sampling area.

$\mathrm{Ca}$ and $\mathrm{K}$ change so much from one sample to another. This could be due to the presence of artificial snow produced with local groundwater, which is carbonate.

The graphs show that the chemical composition of snow is not constant, but changes in several months. This could be due to the presence of transboundary events, which may be studied with isotopic analyzes in the future.

Table 1 shows the ratio between the filtered snow solution and the original snow solution of the main elements analysed by ICP-MS, in each samples of the three periods of sampling.

In the samples of March, particles very large are probably derived from transboundary and no local. The samples taken in correspondence of chair lifts, are the most polluted, and being greater the amount of coarse particles which remain in suspension, the ratio is low (ratio $<1$ ).

In the samples of April, the ratio filtered/suspended of aluminum is lower than in the samples of March, this represent the stop of the chair lifts. While the sample (140 $\mathrm{cm})$ could connect to the period in which the sample $(30$ $\mathrm{cm})$ was taken in the month of March.

In the May samples, the high anomalies in the samples $(250 \mathrm{~cm})$ and $(300 \mathrm{~cm})$ is probably due to the temperature in the sampling period, which was higher than in the two months before. These anomalies could represent the melting snow surface which favored the accumulation of particulate league in the snow below.

Between the concentration of sodium, potassium and aluminum there is a positive correlation. This indicates that the alkaline elements in the Dolomites, being related mainly to allumo silicate, are generally concentrated in the suspended fraction (ratio of filtered/suspended $<1$ ) (Table 1). Despite the lower concentrations of cations,

Table 1. Ratio between the filtered snow solution and the original snow solution of the main elements analysed by ICP-MS, in each samples of the three periods of sampling.

\begin{tabular}{|c|c|c|c|c|c|c|c|c|c|c|c|}
\hline \multirow{3}{*}{ ppm } & \multicolumn{3}{|c|}{ March 11} & \multicolumn{3}{|c|}{ April 11} & \multicolumn{5}{|c|}{ May 12} \\
\hline & $(30 \mathrm{~cm})$ & $(70 \mathrm{~cm})$ & $(130 \mathrm{~cm})$ & $(40 \mathrm{~cm})$ & $(100 \mathrm{~cm})$ & $(140 \mathrm{~cm})$ & $(0 \mathrm{~cm})$ & $(170 \mathrm{~cm})$ & $(250 \mathrm{~cm})$ & $(300 \mathrm{~cm})$ & $(310 \mathrm{~cm})$ \\
\hline & filt/susp & filt/susp & filt/susp & filt/susp & filt/susp & filt/susp & filt/susp & filt/susp & filt/susp & filt/susp & filt/susp \\
\hline $\mathrm{Al}$ & 2.0 & 1.9 & 0.0 & 0.4 & 0.0 & 0.0 & 0.0 & 0.0 & 0.0 & 0.0 & 0.0 \\
\hline $\mathrm{Fe}$ & 0.0 & 3.8 & 0.0 & 0.2 & 0.5 & 3.4 & 0.0 & 0.0 & 0.0 & 0.0 & 0.0 \\
\hline $\mathrm{Ca}$ & 0.1 & 1.0 & 0.2 & 2.8 & 0.0 & 0.0 & 0.0 & 0.0 & 0.0 & 0.0 & 0.0 \\
\hline $\mathrm{Mg}$ & 0.3 & 1.2 & 0.2 & 1.6 & 0.0 & 0.6 & 0.0 & 0.0 & 0.0 & 0.0 & 0.0 \\
\hline K & 0.0 & 0.2 & 0.0 & 0.9 & 0.0 & 0.0 & 0.0 & 0.0 & 0.0 & 0.0 & 0.0 \\
\hline $\mathrm{Na}$ & 0.0 & 0.7 & 0.7 & 0.0 & 0.0 & 0.0 & 0.0 & 0.0 & 0.0 & 0.0 & 0.0 \\
\hline
\end{tabular}



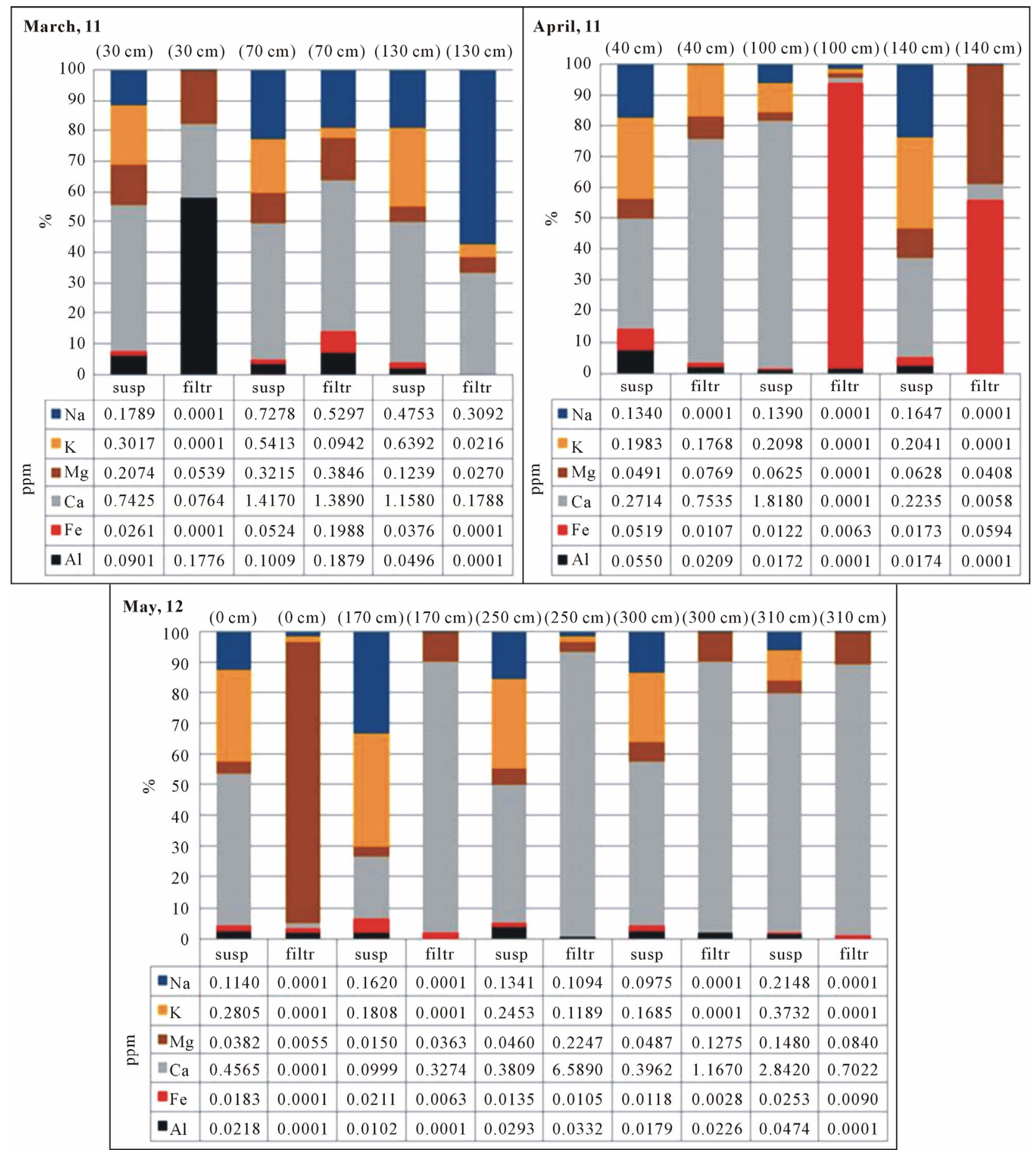

Figure 6. Average concentration of elements analysed by ICP-MS: March, 11; April 11; May, 12.

in the mountain areas there is a greater presence of silicates rich in iron and lower concentration in soluble salts, probably the silicates derive from transboundary sources. The diagram of the particulate sampled in May 2010 (Table 1) shows negative anomalies of sodium, potassium, aluminum and iron, representatives silicate minerals. While higher is the local contribution of carbonates (Ca and $\mathrm{Mg}$ ).

\subsection{Chemical Composition by IC Technique}

The concentrations of anions analyzed are low. In some samples, nitrates and phosphates are under the detection limit (LOD), which represents the minimum concentration of analita detectable (Table 2). Fluorides and phosphates under the detection limit. The symbol "n.d." means "value comparable with white value". 
The sulfate characterizes a mineral acidity in the snow sample. The abnormal presence of sulphate ions could be due to transboundary aerosol. In Italy, the sulfates are destroyed by reducing the amount of fuel with the introduction of geothermal energy and gasoline without sulfur, but in the foreign countries, especially in the east part of Europe, these are not adopted.

The presence of chlorides may be due to pollution anthropic, being the sampling area close enough to the chairlift. It should be noted, in fact, that the concentration of chloride ion decreases from March to May.

The presence of nitrate ion confirms the anthropic activity of the chairlift. Generally, the nitrate ion is very soluble and does not persist in the snow. The high presence of this ion could be explained by the transformation of nitrate ion in nitrite ion. Nitrites are an intermediate metastable and toxic within the chain of bacterial oxidation of proteins (protein-ammonium ion-ion nitrite-nitrate ion). This ion is, therefore, an important indicator of the presence of pollution by organic material, like bacterium Pseudomonas syringae, in the artificial snow. This bacterium is a protein of the cell wall capable of accelerating the crystallization of the water droplets. Normally it is founded on the leaves of many plants and it is rarely free in the soil. Bacterial cells are lyophilized and dissolved in water for the production of artificial snow [80,81]. On this basis, it appears that further study of the particles of particulate present in the snow, especially with microbiological investigations, because the snow itself can be resuspended and with it also these compounds that can be harmful to human health if inhaled.

Table 2. Analysis results by ion chromatography of samples taken in the Dolomites in winter 2010.

\begin{tabular}{cccccc}
\hline \multicolumn{5}{c}{ Ion Chromatography-ANIONS (mg/L) } \\
\hline Date & Sample & $\mathrm{Cl}^{-}$ & $\mathrm{NO}^{2-}$ & $\mathrm{NO}^{3-}$ & $\mathrm{SO}_{4}^{2-}$ \\
\hline $11 / 03 / 10$ & $30 \mathrm{~cm}$ & 0.0704 & n.d. & 0.3824 & 0.0500 \\
$11 / 03 / 10$ & $70 \mathrm{~cm}$ & 0.5710 & n.d. & 2.7652 & 0.9788 \\
$11 / 03 / 10$ & $130 \mathrm{~cm}$ & 0.6846 & n.d. & 0.6575 & 0.4724 \\
$11 / 04 / 10$ & $40 \mathrm{~cm}$ & 0.0873 & n.d. & 0.5942 & 0.2843 \\
$11 / 04 / 10$ & $100 \mathrm{~cm}$ & 0.0754 & n.d. & 0.6293 & 0.1330 \\
$11 / 04 / 10$ & $140 \mathrm{~cm}$ & 0.1826 & n.d. & 0.9560 & 0.0940 \\
$12 / 05 / 10$ & $0 \mathrm{~cm}$ & 0.0299 & n.d. & 0.2493 & 0.1725 \\
$12 / 05 / 10$ & $170 \mathrm{~cm}$ & 0.1613 & 0.148 & 0.0687 & 0.0766 \\
$12 / 05 / 10$ & $250 \mathrm{~cm}$ & 0.0937 & n.d. & 0.2509 & 0.1964 \\
$12 / 05 / 10$ & $300 \mathrm{~cm}$ & 0.0559 & n.d. & 0.1379 & 0.3874 \\
$12 / 05 / 10$ & $310 \mathrm{~cm}$ & 0.0899 & n.d. & 0.2258 & 0.3450 \\
\hline
\end{tabular}

\section{Conclusions}

In this project have been addressed issues of sampling and analytical procedures related to snow samples with very low concentrations and subject to easy contamination. Sampling procedures were determined and the identification of the particulate matter in samples of snow was made by chemical methods (ICP-MS and IC) and observations by SEM-EDS.

The experimental results have allowed for a good response that the analysis of snow can give to estimate the transboundary contributions and possible anthropic impacts.

The snow has not homogeneous composition, which reflects transboundary contributions and it is a good indicator for assessing the regional and local impact.

The SEM analysis, carried out on larger particles, have allowed the identification of the morphology and chemical composition of the various types of particles, which are formed by silicates, allumo silicates, carbonates and organic particles.

From the ICP-MS analysis, the alkaline elements are concentrated in the fraction suspended and they are present as allumo silicates with dimensions larger than those of the filter $(>0.45 \mathrm{~m})$. This indicates that the sea spray and chlorides emitted from incinerators do not have strong effects in mountainous areas.

The strong vertical variations were testimony to the different origin of the snow, which according to its path could be sampled more or less high concentrations of particulate matter but also of a different nature and composition.

The presence of nitrates is important and it is related with nitrites, which were produced by artificial snow. Data obtained from the analysis in IC.

The results suggest a method to use to continue the study of particulate matter in the snow, because it is particularly interesting to estimate the contribution of various pollution sources and to understand the risk factors for people and ecosystems in the sampling area. The snow melted, in fact, favors the interaction of the particles contained in it with biomass. Furthermore, the solid particles in the snow can then be resuspended and be inhaled by humans, with the melting of the snow.

The study of aluminum will be interesting to analyzed because it may be a good tracer to study the formation and the residence time of snow in the upper atmosphere.

\section{REFERENCES}

[1] D.M.60 02/04/2002 capo IV. Recepimento della direttiva 1999/30/CE concernente i valori limite di qualità dell'aria ambiente per biossido di zolfo, biossido di azoto, ossidi di azoto, particelle e piombo e della direttiva 2000/69/CE relativa ai valori limite di qualità aria ambiente per ben- 
zene e monossido di carbonio. G.U. 87, 13/04/2002.

[2] Direttiva 1999/30/CE del Consiglio del 22 aprile 1999. Concernente i valori limite di qualità dell'aria ambiente per il biossido di zolfo, il biossido di azoto, gli ossidi di azoto, le particelle e il piombo. Pubblicato su: Gazzetta ufficiale n. L 163 del 29/06/1999, 0041-0060.

[3] H. Hauck, A. Berner, T. Frischer, B. Gomiscek, M. Kundi, M. Neuberger, H. Puxbaum and O. Preining, "AUPHEPAustrian Project on Health Effects of Particulates - General overview," Atmospheric Environment, Vol. 38, No. 24, 2004, pp. 3905-3915. doi:10.1016/j.atmosenv.2003.09.080

[4] C. L. S. Wiseman and F. Zereini, "Airborne PM, PGE and Human Health: A Review of Recent Evidence," Science of the Total Environment, Vol. 407, No. 8, 2009, pp. 2493-2500. doi:10.1016/j.scitotenv.2008.12.057

[5] P. Primerano, G. Marino, S. Di Pasquale, L. Mavilia and F. Corigliano, "Possible Alteration of Monuments Caused by Particles Emitted into the Atmosphere Carrying Strong Primary Acidity," Atmospheric Environment, Vol. 34, No. 23, 2000, pp. 3889-3896. doi:10.1016/S1352-2310(00)00183-7

[6] M. C. Metallo, A. A. Poli, M. Diana, F. Persia and M. C. Cirillo, "Air Pollution Loads on Historical Monuments: An Air Quality Model Application to the Marble Arch of Titus in Rome," Science of the Total Environment, Vol. 171, No. 1, 1995, pp. 163-172. doi:10.1016/0048-9697(95)04690-0

[7] P. Pongkiatkul and N. Thi Kim Oanh, "Assessment of Potential Long-Range Transport of PM Air Pollution Using Trajectory Modelling and Monitoring data," Atmospheric Research, Vol. 85, No. 1, 2007, pp. 3-17. doi:10.1016/j.atmosres.2006.10.003

[8] P. Salvador, B. Artíñano, X. Querol and A. Alastuey, “A Combined Analysis of Backward Trajectories and Aerosol Chemistry to Characterise Long-Range Transport Episodes of Particulate Matter: The Madrid Air Basin, a Case Study," Science of The Total Environment, Vol. 390, No. 2, 2008, pp. 495-506.

doi:10.1016/j.scitotenv.2007.10.052

[9] U. Forstner and G. Wittmann, "Metal Pollution in the Aquatic Environment," Springer, Berlin, 1983.

[10] J. Nriagu and C. Davidson, "Toxic Metals in the Atmosphere," Wiley Interscience, New York, 1986.

[11] J. Pacyna and B. Ottar, "Control and Fate of Atmospheric Trace Metals," Kluwer, Dordrecht, 1989. doi:10.1007/978-94-009-2315-7

[12] K. Rahn and D. Lowenthal, "Elemental Tracers of Distant Regional Pollution Aerosols," Science. Vol. 223, No. 4632, 1984, pp. 132-139. doi:10.1126/science.223.4632.132

[13] L. Barrie, S. Lindburg, W. Chen, H. Ross, R. Arimoto and T. Church, "On the Concentrations of Trace Metals in Precipitation," Atmospheric Environment, Vol. 21, 1987, pp. 113-1135. doi:10.1016/0004-6981(87)90240-X

[14] T. P. Franz and S. J. Eisenreich, "Snow Scavenging of Polychlorinated Biphenyls and Polycyclic Aromatic Hydrocarbons in Minnesota," Environmental Science and
Technology, Vol. 32, No. 12, 1998, pp. 1771-1778. doi:10.1021/es $970601 \mathrm{z}$

[15] F. Wania, R. Semkin, J. T. Hoff and D. Mackay, "Modeling the Fate of Non-Polar Organic Chemicals during the Melting of an Arctic Snowpack," Hydrological Processes, Vol. 13, No. 14-15, 1999, pp. 2245-2256.

doi:10.1002/(SICI)1099-1085(199910)13:14/15<2245::A ID-HYP889>3.0.CO;2-7

[16] B. M. J. Herbert, C. J. Halsall, L. Fitzpatrick, S. Villa, K. C. Jones and G. O. Thomas, "Use and Validation of Novel Snow Samplers for Hydrophobic, Semi-Volatile Organic Compounds (SVOCs)," Chemosphere, Vol. 56, No. 3, 2004, pp. 227-235.

doi:10.1016/j.chemosphere.2004.03.004

[17] J. M. Blais, D. W. Schindler, D. C. G. Muir, M. Sharp, D. Donald, M. Lafrenière, E. Braekevelt and W. M. J. Strachan, "Melting Glaciers Are a Dominant Source of Persistent Organochlorines to Subalpine Bow Lake in Banff National Park, Canada," Ambio, Vol. 30, 2001, pp. 410415.

[18] J. M. Blais, D. W. Schindler, M. Sharp, E. Braekevelt, M. Lafrenière, K. McDonald, D. C. G. Muir and W. M. J. Strachan, "Fluxes of Semi-Volatile Organochlorines in Bow Lake, a Remote High Altitude, Glacier-Fed SubAlpine Lake in the Canadian Rocky Mountains," Limnology and Oceanography, Vol. 46, 2001, pp. 2019-2031. doi:10.4319/10.2001.46.8.2019

[19] A. J. Peters, D. J. Gregor, C. F. Teixeira, N. P. Jones and C. Spencer, "The Recent Depositional Trend of Polycyclic Aromatic Hydrocarbons and Elemental Carbon to the Agassiz Ice Cap, Ellesmere Island, Canada," Science of the Total Environment, Vol. 160-161, 1995, pp. 167-179. doi:10.1016/0048-9697(95)04354-4

[20] D. B. Donald, J. Syrgiannia, R. W. Crosley, G. Holdsworth, D. C. G. Muir, B. Rosenberg, A. Sole and D. W. Schindler, "Delayed Deposition of Organochlorine Pesticides at a Temperate Glacier," Environmental Science and Technology, Vol. 33, 1999, pp. 1794-1798. doi:10.1021/es981120y

[21] C. Gröllert, A. Kasper and H. Puxbaum, "Organic Compounds in High Alpine Snow," International Journal of Environmental Analytical Chemistry, Vol. 67, No. 1, 1997, pp. 213-222. doi:10.1080/03067319708031405

[22] J. M. Blais, D. W. Schindler, D. C. G. Muir, L. E. Kimpe, D. Donald and B. Rosenberg, "Accumulation of Persistent Organochlorine Compounds in Mountains of Western Canada," Nature, Vol. 395, No. 6702, 1998, pp. 585588. doi:10.1038/26944

[23] J. E. Kay, A. R. Gillespie, G. B. Hansen and E. C. Pettit, "Spatial Relationship between Snow Contaminant Content, Grain Size and Surface Temperature from Multispectral Images of Mt. Rainier, Washington, (USA)," Remote Sensing of Environment, Vol. 86, No. 2, 2003, pp. 216-231. doi:10.1016/S0034-4257(03)00102-0

[24] K. Higuchi and A. Nagoshi, "Effect of Particulate Matter in Surface Snow Layers on the Albedo of Perennial Snow Patches, Isotopes and Impurities in Snow and Ice Symposium," Proceedings of the Grenoble, 1975, pp. 95-98.

[25] S. Warren and W. Wiscombe, "A Model for the Spectral 
Albedo of Snow: II. Snow Containing Atmospheric Aerosols," Journal of Atmospheric Science, Vol. 37, 1981, pp. 2734-2745. doi:10.1175/1520-0469(1980)037<2734:AMFTSA $>2.0$.C $\underline{\mathrm{O} ; 2}$

[26] S. Hong, J. P. Candelone, C. C. Patterson and C. F. Boutron, "Greenland Ice Evidence of Hemispheric Scale Pollution for Lead Two Millennia Ago by Greek and Roman Civilizations," Science Vol. 295, 1994, pp. 1841-1843. doi:10.1126/science.265.5180.1841

[27] K. J. R. Rosman, W. Chisholm, S. Hong, J. P. Candelone and C. F. Boutron, "Lead from Carthaginian and Roman Spanish Mines Isotopically Identified in Greenland Ice Dated from $600 \mathrm{BC}$ to $300 \mathrm{AD}$," Environmental Science and Technology, Vol. 31, No. 12, 1997, pp. 3413-3416. doi:10.1021/es970038k

[28] M. Murozumi, T. J. Chow and C. C. Patterson, "Chemical Concentrations of Pollutant Aerosols, Terrestrial Dusts and Sea Salts in Greenland and Antarctic Snow Strata," Gechimica Cosmochimica Acta, Vol. 33, 1969, pp. 12471249. doi:10.1016/0016-7037(69)90045-3

[29] C. F. Boutron, U. Görlach, J. P. Candelone, M. A. Bolshov and R. J. Delmas, "Decrease in Anthropogenic Lead, Cadmium and Zinc in Greenland Snows Since the Late 1960s," Nature, Vol. 353, No. 6340, 1991, pp. 153-156. doi:10.1038/353153a0

[30] J. P. Candelone, S. Hong, C. Pellone and C. F. Boutron, "Industrial Revolution Changes in Large Scale Atmospheric Pollution of the Northern Hemisphere for Heavy Metals as Documented in Central Greenland Snow and Ice," Journal of Geophysical Research, Vol. 100, 1995, pp. 605-616.

[31] C. F. Boutron, G. M. Vandal, W. F. Fitzgerald and C. P. Ferrari, "A Forty Year Record of Mercury in Central Greenland Snow," Geophysical Research Letters, Vol. 25, 1998, pp. 3315-3318. doi:10.1029/98GL02422

[32] C. Barbante, A. Veysseyre, C. Ferrari, K. Van de Velde, C. Morel, G. Capodoglio, P. Cescon, G. Scarponi and C. F. Boutron, "Greenland Snow Evidence of Large Scale Atmospheric Contamination for Platinum, Palladium and Rhodium," Environmental Science and Technology, Vol. 35, No. 5, 2001, pp. 835-839. doi:10.1021/es000146y

[33] K. J. R. Rosman, W. Chisholm, C. F. Boutron, J. P. Candelone and C. C. Patterson, "Anthropogenic Lead Isotopes in Antarctica," Geophysical Research Letters, Vol. 21, No. 24, 1994, pp. 2669-2672. doi:10.1029/94GL02603

[34] E. W. Wolff and E. D. Suttie, "Antarctic Snow Record of Southern Hemisphere Lead Pollution," Geophysical Research Letters, Vol. 21, No. 9, 1994, pp. 781-784. doi:10.1029/94GL00656

[35] E. W. Wolff, E. D. Suttie and D. A. Peel, "Antarctic Snow Record of Cadmium, Copper and Zinc Content during the Twentieth Century," Atmospheric Environment, Vol. 33, No. 10, 1999, pp. 1535-1541. doi:10.1016/S1352-2310(98)00276-3

[36] F. Planchon, C. F. Boutron, C. Barbante, G. Cozzi, V. Gaspari, E. W. Wolff, C. Ferrari and P. Cescon, "Changes in Heavy Metals in Antarctic Snow from Coats Land since the Mid-19th to the Late 20th Century," Earth and Planetary Science Letters, Vol. 200, No. 1-2, 2002, pp. 207-222. doi:10.1016/S0012-821X(02)00612-X

[37] F. Planchon, K. van de Velde, K. J. R. Rosman, E. W. Wolff, C. Ferrari and C. F. Boutron, "One-Hundred Fifty-Year Record of Lead Isotopes in Antarctic Snow from Coats Land," Geochimica et Cosmochimica Acta, Vol. 67, No. 4, 2003, pp. 693-708. doi:10.1016/S0016-7037(02)01136-5

[38] P. Vallelonga, K. van de Velde, J. P. Candelone, V. I. Morgan, C. F. Boutron and K. J. R. Rosman, "The Lead Pollution History of Law Dome, Antarctica, from Isotopic Measurements on Ice Cores: 1500 AD to 1989 AD," Earth and Planetary Science Letters, Vol. 204, No. 1-2, 2002, pp. 291-306. doi:10.1016/S0012-821X(02)00983-4

[39] C. Barbante, C. F. Boutron, C. Morel, C. Ferrari, J. L. Jaffrezo, G. Cozzi, V. Gaspari and P. Cescon, "Seasonal Variations of Heavy Metals in Central Greenland Snow Deposited from 19991 to 1995," Journal of Environmental Monitoring, Vol. 5, 2003, pp. 328-335. doi:10.1039/b210460a

[40] P. Gabrielli, C. Barbante, C. F. Boutron, G. Cozzi, V. Gaspari, F. Planchon, C. Ferrari and P. Cescon, "Variations in Atmosphere Trace Elements in Dome C (East Antarctica) Ice over the Last Two Climatic Cycles," Atmospheric Environment, Vol. 39, No. 34, 2005, pp. 64206429. doi:10.1016/j.atmosenv.2005.07.025

[41] W. Shotyk, J. Zheng, M. Krachler, C. Zdanowicz, R. M. Koerner and D. Fischer, "Predominance of Industrial $\mathrm{Pb}$ in Recent Snow (1994-2004) and Ice (1842-1996) from Devon Island, Arctic Canada," Geophysical Research Letters, Vol. 32, No. 21, 2005. doi:10.1029/2005GL023860

[42] K. van de Velde, C. P. Ferrari, C. Barbante, I. Moret, T. Bellomi, S. Hong and C. F. Boutron, "A 200 Year Record of Atmospheric Cobalt, Chromium, Molybdenum and Antimony in High Altitude Alpine Firn and Ice," Environmental Science and Technology, Vol. 33, No. 20, 1999, pp. 3495-3501. doi:10.1021/es990066y

[43] K. Van de Velde, C. Barbante, G. Cozzi, I. Moret, T. Bellomi, C. P. Ferrari and C. F. Boutron, "Changes in the Occurrence of Silver, Gold, Platinum, Palladium and Rhodium in Mont Blanc Ice and Snow Since the 18th Century," Atmospheric Environment, Vol. 34, No. 19, 2000, pp. 3117-3127.

[44] K. van de Velde, C. F. Boutron, C. P. Ferrari, A. L. Moreau, R. J. Delmas, C. Barbante, T. Bellomi and G. Capodoglio, "A 200 Years Record of Atmospheric Cadmium, Copper and Zinc Concentrations in High Altitude Snow and Ice from the French-Italian Alps," Geophysical Research Letters, Vol. 27, No. 2, 2000, pp. 249-252. doi:10.1029/1999GL010786

[45] K. J. R. Rosman, C. Ly, K. Van de Velde and C. F. Boutron, "A Two Century Record of Lead Isotopes in High Altitude Alpine Snow and Ice," Earth and Planetary Science Letters, Vol. 176, No. 3-4, 2000, pp. 413424. doi:10.1016/S0012-821X(00)00013-3

[46] C. Barbante, K. van de Velde, G. Cozzi, G. Capodoglio, P. Cescon, F. Planchon, S. Hong, C. Ferrari and C. F. Bou- 
tron, "Post-World War II Uranium Changes in Dated Mont Blanc Ice and Snow," Environmental Science and Technology, Vol. 35, No. 20, 2001, pp. 4026-4030. doi:10.1021/es0109186

[47] C. Barbante, C. F. Boutron, A. L. Moreau, C. Ferrari, K. van de Velde, G. Cozzi, C. Turetta and P. Cescon, "Seasonal Variations in Nickel and Vanadium in Mont Blanc Snow and Ice Dated from the 1960s and 1990s," Journal of Environmental Monitoring, Vol. 4, 2002, pp. 960-966. doi: $10.1039 / \mathrm{b} 208142 \mathrm{c}$

[48] M. Schwikowski, C. Barbante, T. Doering, H. W. Gaeggeler, C. F. Boutron, U. Schotterer, L. Tobler, K. van de Velde, C. Ferrari, G. Cozzi, K. Rosman and P. Cescon, "Post-17th Century Changes of European Lead Emissions Recorded in High-Altitude Alpine Snow and Ice," Environmental Science and Technology, Vol. 38, No. 4, 2004, pp. 957-964. doi:10.1021/es034715o

[49] S. Hong, C. Barbante, C. F. Boutron, P. Gabrielli, V. Gaspari, P. Cescon, D. S. Thomson, C. Ferrarai and B. Francou, "Atmospheric Heavy Metals in Tropical South America during the Past 22,000 Years Recorded in a High Altitude Ice Core from Sajama, Bolivia," Journal of Environmental Monitoring, Vol. 6, 2004, pp. 222-226. doi:10.1039/b314251e

[50] Z. Li, C. Li, Y. Li, F. Wang and H. Li, "Preliminary Results from Measurements of Selected Trace Metals in the Snow-Firn Pack on Urumqi Glacier, China," Journal of Glaciology, Vol. 53, No. 182, 2007, pp. 368-373. doi:10.3189/002214307783258486

[51] Y. Li, T. Yao, N. Wang, Z. Li, L. Tian, B. Xu and G. Wu, "Recent Changes of Atmospheric Heavy Metals in a High-Elevation Ice Core from Muztagh Ata in East Pamirs: Initial Results," Annals of Glaciology, Vol. 43, No. 1, 2006, pp. 154-159. doi:10.3189/172756406781812186

[52] Z. Li, T. Yao, B. Xu and Y. Li, "Atmospheric Pb Variations in Central Asia Since 1955 from Muztaghata Ice Core Record, Eastern Pamirs," Chinese Science Bulletin, Vol. 51, No. 16, 2006, pp. 1996-2000. doi:10.1007/s11434-006-2061-9

[53] S. Kang, Q. Zhang, S. Kaspari, D. Qin, Z. Cong, J. Ren and P. A. Mayewski, "Spatial and Seasonal Variations of Elemental Composition in Mt. Everest (Qomolangma) Snow/Firn," Atmospheric Environment, Vol. 41, No. 34, 2007, pp. 7208-7218.

doi:10.1016/i.atmosenv.2007.05.024

[54] J. Duan, J. Ren, X. Qin and Y. Li, "Heavy Metal Concentrations and Seasonal Variations in Snow of Mount Everest Region," Acta Geographica Sinica, Vol. 62, No. 1, 2007, pp. 22-29.

[55] K. Lee, D. S. Hur, S. Hou, S. Hong, X. Qin, J. Ren, Y. Liu, K. J. R. Rosman, C. Barbante and C. F. Boutron, "Atmospheric Pollution for Trace Elements in the Remote High-Altitude Atmosphere in Central Asia as Record in Snow from Mt. Qomolangma," Science of The Total Environment, Vol. 404, No. 1, 2008, pp. 171-181. doi:10.1016/i.scitotenv.2008.06.022

[56] T. D. Jickells, T. D. Davies, M. Tranter, S. Landsberger, K. Jarvis and P. Abrahams, "Trace Elements in Snow Samples from the Scottish Highlands: Sources and Dis-
solved/Particulate Distributions," Atmospheric Environment, Vol. 26, No. 3, 1992, pp. 393-401. doi:10.1016/0960-1686(92)90325-F

[57] P. Gabrielli, G. Cozzi, S. Torcini, P. Cescon and C. Barbante, "Trace Elements in Winter Snow of the Dolomites (Italy): A Statistical Study of Natural and Anthropogenic Contributions," Chemosphere, Vol. 72, No. 10, 2008, pp. 1504-1509. doi:10.1016/j.chemosphere.2008.04.076

[58] J. Lelieveld, P. J. Crutzen, V. Ramanathan, M. O. Andreae, C. A. M. Brenninkmeijer, T. L. Campos, G. R. Cass, R. R. Dickerson, H. Fischer, D. Sikka and J. Williams, "The Indian Ocean Experiment: Widespread Air Pollution from South and Southeast Asia," Science, Vol. 291, No. 5506, 2001, pp. 1031-1036. doi:10.1126/science. 1057103

[59] G. C. Fang, Y. S. Wu, S. H. Huang and J. Y. Rau, "Review of Atmospheric Metallic Elements in Asia during 2000-2004," Atmospheric Environment, Vol. 39, No. 17, 2005, pp. 3003-3013. doi:10.1016/j.atmosenv.2005.01.042

[60] A. Correia, R. Freydier, R. F. Delmas, J. C. Simoes, J. D. Taupin, B. Dupré and P. Artaxo, "Trace Elements in South America Aerosol during 20th Century Inferred from a Nevado Illimani Ice Core, Eastern Bolivian Andes (6350 $\mathrm{m}$ asl)," Atmospheric Chemistry and Physics, Vol. 3, 2003, pp. 1337-1352. doi:10.5194/acp-3-1337-2003

[61] M. Schwikowski, "Reconstruction of European Air Pollution from Alpine Ice Cores," Developments in Paleoenvironmental Research, Vol. 9, 2003, pp. 95-119.

[62] C. Barbante, M. Schwikowski, T. Doring, H. W. Gaggeler, U. Shottered, L. Tobler, K. Van de Velde, C. Ferrari, G. Cozzi, A. Turetta, K. Rosman, M. A. Bolshov, G. Capodaglio, P. Cescon and C. F. Boutron, "Historical Record of European Emission if Heavy Metal to the Atmosphere Since the 1650s from Alpine Snow/Ice Cores Drilled near Monte Rosa," Environmental Science and Technology, Vol. 38, No. 15, 2004, pp. 4085-4090. doi:10.1021/es049759r

[63] A. Veysseyre, K. Moutard, C. Ferrari, K. van de Velde, C. Barbante, G. Cozzi, G. Capodaglio and C. F. Boutron, "Heavy Metals in Fresh Snow Collected at Different Altitudes in the Chamonix and Maurienne Valleys, French Alps: Initial Results," Atmospheric Environment, Vol. 35, No. 2, 2001, pp. 415-425. doi:10.1016/S1352-2310(00)00125-4

[64] C. Dossi, E. Ciceri, B. Giussani, A. Pozzi, A. Galgaro, A. Viro and A. Vigano, "Water and Snow Chemistry of Main Ions and Trace Elements in the Karst System of Monte Pelmo Massif (Dolomites, Eastern Alps, Italy)," Marine \& Freshwater Research, Vol. 58, No. 7, 2007, pp. 649-656. doi:10.1071/MF06170

[65] N. Hiranuma, S. D. Brooks, B. W. Auvermann and R. Littleton, "Using Environmental SEM to Determine Hygroscopic Properties of Agricultural Aerosols," Atmospheric Environment, Vol. 42, No. 9, 2008, pp. 1983-1994. doi:10.1016/j.atmosenv.2007.12.003

[66] H. Haapala, "The Use of SEM/EDX for Studying the Distribution of Air Pollutants in the Surroundings of the Emission Source," Environmental Pollution, Vol. 9, No. 
3, 1998, pp. 361-363. doi:10.1016/S0269-7491(98)00025-6

[67] R. S. Frankel and D. W. Aitken, "Energy Dispersive X-Ray Emission Spectroscopy," Applied Spectroscopy, Vol. 24, No. 6, 1970, pp. 557-566. doi:10.1366/000370270774372308

[68] K. Wilkinson, J. Lundkvist, G. Seisenbaeva and V. Kessler, "New Table Top SEM-EDS-Based Approach for CostEfficient Monitoring of Airborne PM," Environmental Pollution, Vol. 159, No. 1, 2011, pp. 311-318. doi:10.1016/j.envpol.2010.08.024

[69] H. H. Yang, L. T. Hsieh and S. K. Cheng, "Determination of Atmospheric Nitrate Particulate Size Distribution and Dry Deposition Velocity for Three Distinct Areas," Chemosphere, Vol. 60, No. 10, 2005, pp. 1447-1453. doi:10.1016/j.chemosphere.2005.01.067

[70] F. Goodarzi, "Morphology and Chemistry of Fine Particles Emitted from a Canadian Coal-Fired Power Plant," Fuel, Vol. 85, No. 3, 2006, pp. 273-280. doi:10.1016/j.fuel.2005.07.004

[71] A. M. S. De La Campa, J. De La Rosa, X. Querol, A. Alastuey and E. Mantilla, "Geochemistry and Origin of $\mathrm{PM}_{10}$ in the Huelva Region, Southwestern Spain," Environmental Research, Vol. 103, No. 3, 2007, pp. 305-316. doi:10.1016/i.envres.2006.06.011

[72] H. Fromme, J. Diemer, S. Dietrich, J. Cyrys, J. Heinrich, W. Lang, M. Kiranoglu and D. Twardella, "Chemical and Morphological Properties of Particulate Matter $\left(\mathrm{PM}_{10}\right.$ and $\mathrm{PM}_{2.5}$ ) in School Classrooms and Outdoor Air," Atmospheric Environment, Vol. 42, No. 27, 2008, pp. 65976605. doi:10.1016/j.atmosenv.2008.04.047

[73] A. Campos-Ramos, A. Aragón-Piña, I. Galindo-Estrada, X. Querol and A. Alastuey, "Characterization of Atmospheric Aerosols by SEM in a Rural Area in the Western Part of México and Its Relation with Different Pollution Sources," Atmospheric Environment, Vol. 43, No. 39, 2009, pp. 6159-6167. doi:10.1016/j.atmosenv.2009.09.004

[74] J. Upadhyay, B. J. Majestic, P. Prapaipong and P. Herckes, "Evaluation of Polyurethane Foam, Polypropylene,
Quartz Fiber, and Cellulose Substrates for Multi-Element Analysis of Atmospheric Particulate Matter by ICP-MS," Analytical and Bioanalytical Chemistry, Vol. 394, No. 1, 2009, pp. 255-266. doi:10.1007/s00216-009-2671-6

[75] R. Arimoto, R. A. Duce, B. J. Ray, W. G. Ellis, J. D. Cullen and J. T. Merrill, "Trace Elements in the Atmosphere over the North Atlantic," Journal of Geophysical Research: Atmospheres, Vol. 100, No. D1, 1995, pp. 1199 1213.

[76] M. Bettinelli, S. Spezia, U. Baroni and G. Bizzarri, "Determination of Trace Elements in Power Plant Emissions by Inductively Coupled Plasma Mass Spectrometry: Comparison with Other Spectrometric Techniques," Microchemical Journal, Vol. 59, No. 2, 1998, pp. 203-218. doi:10.1006/mchj.1998.1600

[77] M. Vallius, N. A. H. Janssen, J. Heinrich, G. Hoek, J. Ruuskanen, J. Cyrys, R. Van Griecken, J. J. De Hartog, W. G. Kreyling and J. Pekkanen, "Sources and Elemental Composition of Ambient $\mathrm{PM}_{2.5}$ in Three European Cities," Science of the Total Environment, Vol. 337, No. 1-3, 2005, pp. 147-162. doi:10.1016/j.scitotenv.2004.06.018

[78] J. D. Herner, P. G. Green and M. J. Kleeman, "Measuring the Trace Elemental Composition of Size-Resolved Airborne Particles," Environmental Science and Technology, Vol. 40, No. 6, 2006, pp. 1925-1933. doi:10.1021/es052315q

[79] M. Witt, A. R. Baker and T. D. Jickells, "Atmospheric Trace Metals over the Atlantic and South Indian Oceans: Investigation of Metal Concentrations and Lead Isotope Ratios in Coastal and Remote Marine Aerosols," Atmospheric Environment, Vol. 40, No. 28, 2006, pp. 54355451. doi:10.1016/j.atmosenv.2006.04.041

[80] G. Feliziani, "De Innevamento Artificiale. L'Opinione," MeteoLive.it, 2009. http://meteolive.leonardo.it/news/I-vostri-articoli/10/-De-I nnevamento-artificiale-1-opinione/27626/

[81] A. Grosso, "Porcherie Emesse dai Cannoni da Neve?" MeteoLive.it, 2011. http://meteolive.leonardo.it/news/In-primo-piano/2/Porch erie-emesse-dai-cannoni-da-neve-/35054/ 